Board of Governors of the Federal Reserve System

International Finance Discussion Papers

Number 518

August 1995

\title{
ALTERINATIVE APPROACHES TO REAL EXCHANGE RATES AND REAL INTEREST RATES: THREE UP AND THREE DOWN
}

\author{
Hali J. Edison and William R. Melick
}

NOTE: International Finance Discussion Papers are preliminary materials circulated to stimulate discussion and critical comment. References in publications to International Finance Discussion Papers (other than an acknowledgement that the writer has had access to unpublished material) should be cleared with the author or authors. 


\begin{abstract}
This paper examines the relationship between real exchange rates and real interest rates using three different approaches across four currencies and two horizons with 20 years of data. Each approach gives some encouragement that this relationship might hold, but each approach also encounters problems establishing the form or usefulness of the relationship. On balance, this paper contributes to the literature by finding more encouraging results than in earlier studies, but it still remains to be demonstrated that the real exchange rate-real interest rate relationship is the linchpin to explaining exchange rate movements.
\end{abstract}




\title{
Alternative Approaches to Real Exchange Rates and Real Interest Rates: Three Up and Three Down
}

\author{
Hali J. Edison and William R. Melick ${ }^{1}$
}

\section{Introduction}

The difficulty of modelling exchange rates has been a persistent problem in international economics. In the decade immediately after the move to generalized floating, the focus of research was on the development and estimation of relatively complicated empirical models of floating exchange rates. By the early 1980s these early apparent empirical successes were overturned by the seminal paper of Meese and Rogoff (1983). Their result was that no existing structural exchange rate model could reliably out-predict a naive random walk model. ${ }^{2}$ More recent research has focused on using a simple model relating the real exchange rate to the real interest rate differential using increasingly more sophisticated time series econometrics. This paper resumes the debate on the relationship between real exchange rates and real interest rate differentials, by investigating the link between them using over 20 years of data.

Figure 1 plots the trade-weighted value of the U.S. dollar against the other G-10 currencies, together with a measure of the corresponding long-term real interest differential. The impression from this figure is that the real exchange rate and real interest rate differential exhibit the same overall shape, although their short-term movements do not appear to be closely related. This paper asks has two questions: Is there a systematic relationship between the real exchange rate and the real interest rate differential? What empirical representation of the relationship is supported by the data?

Empirical work on the link between real exchange rates and real interest rate differentials has been carried out by a number of authors using a variety of techniques. In general, these results have been mixed. Two of the more well-known papers are those of Campbell and Clarida (1987) and Meese and Rogoff (1988). Campbell and Clarida examine whether expected real interest rate

\footnotetext{
${ }^{1}$ The authors are economists in the Division of International Finance, Board of Governors of the Federal Reserve System. We would like to thank Jon Faust for helpful discussions. We also acknowledge the helpful comments of John Ammer, Allan Brunner, Neil Ericsson, William Helkie, Peter Hooper, Karen Johnson, Jaime Marquez, John Rogers, and Ralph Smith. The views expressed in this paper are solely the responsibility of the authors and should not be interpreted as reflecting those of the Board of Governors of the Federal Reserve System or other members of its staff.

${ }^{2}$ There have been numerous attempts in the literature to overturn this result. See, for example, the citations in the surveys by Frankel and Rose (1994) and Taylor (1995). Mark (1994), however, shows that long horizon changes in the exchange rate are predictable.
} 
differentials can explain sizable variation in real exchange rates and find that little of the movement in real exchange rates is attributable to movement in real interest rate differentials. Meese and Rogoff focus on the long-run relationship and test for cointegration between the two variables. They find they cannot reject the null hypothesis of noncointegration between real long-term interest rate differentials and real exchange rates using the single-equation Engle-Granger cointegration testing procedure. ${ }^{3}$ Meese and Rogoff suggest that their finding might indicate that including an omitted variable with a large variance -- possibly the expected value of some future exchange rate -- would lead to a finding of cointegration.

Edison and Pauls (1993) use a similar methodology to Meese and Rogoff and reach essentially the same results. ${ }^{4}$ Specifically, they also fail to find a statistical link between real exchange rates and real interest rate differentials using the Engle-Granger methodology. In contrast, Coughlin and Koedijk (1990) and Blundell-Wignall and Browne (1991) using the Engle-Granger methodology find that real exchange rates and real interest rates may be cointegrated. Blundell-Wignall and Browne include the difference in the share of cumulated current account relative to GNP in the relevant countries (also tested and rejected in Edison and Pauls) and find cointegration; while Coughlin and Koedijk extend the Meese-Rogoff sample period for the mark/dollar exchange rate and find support for the theory.

Further evidence recently has been more supportive of the relationship. For example, Baxter (1994) decomposes real exchange rate movements into permanent and temporary components and finds that temporary movements in the real exchange rate are linked with real interest rate differentials, especially when using a multivariate framework. ${ }^{5}$ However, like previous researchers, she finds that real interest differentials do not explain a great deal of the variance in the temporary components of real exchange rates. Edison and Melick (1992), using the same dataset as Edison and Pauls but a

\footnotetext{
${ }^{3}$ Meese and Rogoff find that real short-term interest differentials are stationary, therefore they do test for cointegration between short-term real rates and real exchange rates. Their interest rate differential is formed by taking either the annualized three-month or long-term nominal interest rate differential and subtracting off the annualized ex post realized three-month inflation differential for short-term rates and the last twelve months' inflation for long-term rates.
}

${ }^{4}$ They focus primarily on long-term rates and consider three different proxies for expected inflation:a twelve quarter centered moving average of actual inflation, a four-quarter change in the CPI, and a one-quarter annualized change in the CPI.

${ }^{5}$ Baxter uses short-term and long-term interest rates and computes the expected inflation differential as the ex post annualized one-quarter ahead inflation differential. 
different econometric methodology (the Full Information Maximum Likelihood procedure proposed by Johansen), find a cointegrating vector between most real exchange rate-real interest rate pairs. However, they are not able to identify the cointegrating vector and therefore they fail to establish the cointegrating relationship between real exchange rates and real interest rates. In closely related studies, Johansen and Juselius (1992) and Hunter (1992) test whether purchasing power parity and uncovered interest rate parity are supported by the data using the trade-weighted value of the UK pound. Both of these studies use the multivariate cointegration approach of Johansen using a 5variable VAR in which the relationship between nominal exchange rates, domestic and foreign prices, and domestic and foreign nominal interest rates are tested. In general, these studies find some support for purchasing power parity and uncovered interest rate parity, which is supportive evidence of a relationship between real exchange rates and real interest rates.

The upshot of all of this previous work suggests that perhaps it is time to revisit this question of the existence of the relationship between real exchange rates and real interest rates. This paper examines this question using three different approaches across four currencies and two horizons with 20 years of data. Each approach yields some encouraging results that a long-run relationship might hold in the data, but each approach encounters problems that raise some doubt about the existence of the relationship. On balance, this paper contributes to the literature by finding more encouraging results, but it still remains to be demonstrated that the real exchange rate-real interest rate relationship is the linchipin to explaining exchange rate movements.

The remainder of the paper is organized as follows: Section 2 describes the data used in the analysis. Section 3 presents some definitions and formalizes the relationship between real exchange rates and real interest rates. Section 4 gives the econometric results and section 5 concludes.

\section{The Data}

The issues in this paper are fundamentally empirical; therefore, we discuss the data first. We use four exchange rates and two horizons over the period 1974 to 1994 to gauge the robustness of our findings. The exchange rates are all noon New York rates; three bilateral rates against the dollar (Canadian dollar, German mark, and Japanese yen) and the Federal Reserve Board staff's tradeweighted value of the dollar against the G-10 currencies. The time horizons are short-term (three months) and long-term (roughly seven years).

To construct real rates of interest for the short-term horizon we use three-month nominal interbank rates for the foreign rates and the three-month Treasury bill rate for the United States. For 
the long-term horizon, nominal interest rates are yields on 10-year bellwether government bonds for the foreign rates and the yield on a 10-year constant maturity Treasury bond for the United States. ${ }^{6}$ Due to their coupon payments these rates are only proxies for the preferable but unavailable yields from pure discount bonds. ${ }^{7}$ As is often done in term structure analysis, we use the coupon bonds to approximate the yield on a pure discount bond of shorter maturity. Given the usual slope of the yield curve in our data sample, the ten-year coupon bonds should be good proxies for roughly seven-year pure discount bonds. ${ }^{8}$ We will maintain this assumption throughout the rest of our analysis, viewing our long-term results as applying to a seven year horizon.

Consumer price indices (CPIs) are used to calculate the real exchange rate and to measure inflation. A 4-quarter backward change in the CPI index is used to deflate the three-month nominal interest rates, while a 12-quarter centered moving average of the CPI inflation rate is used to deflate the nominal 10-year interest rates. ${ }^{9}$ All data are at a quarterly frequency taken from the end of period. Further details on data sources and data construction can be found in Appendix A.

\subsection{Plots and Univariate Statistical Results}

Figure 2 contains plots of the real exchange rates. Panel 1 shows that the Canadian dollar has been relatively flat over the sample period. In contrast, panel 3 shows that the yen has steadily appreciated against the dollar since 1985. Not surprisingly, the movement of the trade-weighted dollar exchange rate (panel 4) mirrors that of the mark (panel 2) since the mark and the other European currencies tied closely to it combine to carry a large trade weight. Figure 3 plots long-term and shortterm real interest rates. Short-term real rates show considerably more variation than do the long-term rates. However, the long-term real rates which we use that embody the centered moving average inflation measures tend to be smoother than ex post measures that might be used (see Baxter (1994)).

The choice of the subsequent estimation techniques will depend upon assumptions about the stationarity of the real exchange rate, real interest rates, and real interest rate differentials. Typically,

\footnotetext{
${ }^{6}$ In most of the foreign G-10 countries, the liberalization of financial markets is a fairly recent phenomenon. Previously, ten-year bonds did not exist in may of these countries. For the early part of our sample, we used the best available proxy - often an average yield on a set of bonds of intermediate maturity.

${ }^{7}$ The yields from a coupon bond and a pure discount bond that share the same maturity will be equal only when the yield curve is flat.

${ }^{8}$ See Faust (1994) for an extended discussion and numerical examples.

${ }^{9}$ These inflation constructs match those found in Edison and Pauls (1993).
} 
the real exchange rate is assumed nonstationary or integrated of order one (I(1)). There is no consensus about the statistical properties of real interest rates or real interest differentials. Therefore, we use the Augmented Dickey-Fuller (ADF) and the Kwiatkowski, Phillips, Schmidt, and Shin (KPSS) tests to assess the stationarity properties of our data. The ADF test maintains the null hypothesis that the time series has a unit root. Thus, an insignificant ADF test statistic is a non-rejection of the null hypothesis; i.e. it is evidence that the time series has a unit root. The KPSS test maintains the null hypothesis of no unit root in the time series. Hence, an insignificant KPSS test statistic is a nonrejection of the null hypothesis; i.e. it is evidence that the time series does not have a unit root. It is quite possible for the two tests to point to different conclusions in small (finite) samples.

Table 1 reports the results for the ADF and KPSS tests for the real exchange rates, real interest rates, and real interest rate differentials. Given that none of the time series displays an obvious time trend (see Figures 2 and 3), we used forms of the two tests that entertain level, as opposed to trend, stationarity. The ADF tests use a lag length of 4 , while the KPSS tests use a lag truncation parameter of $8 .^{10}$ Significant test statistics are marked with a star, using the asymptotic critical values found in Fuller (1975) for the ADF test and in Kwiatkowski, Phillips, Schmidt, and Shin (1992) for the KPSS test. The results in Table 1 warrant the following conclusions:

- With the exception of Japan, there is as much evidence that the real exchange rate is $I(1)$ as there is that it is $I(0)$. That is, neither test for the real exchange rates rejects its null hypothesis. For the Japanese real exchange rate, both tests point to I(1) behavior, perhaps explained by the recent appreciation of the Japanese real exchange rate.

- Ely and large, the real interest rates appear to be I(1) variables. With a few exceptions, these series display insignificant ADF tests and significant KPSS tests.

- For the most part short-term real interest differentials appear stationary. These series typically exhibit significant ADF tests and insignificant KPSS tests.

- The results for long-term real interest rate differentials are mixed

\footnotetext{
${ }^{10}$ As noted in Kwiatkowski, Phillips, Schmidt, and Shin (1992), test results are sensitive with respect to the lag truncation parameter. Generally, an increase in the parameter leads to a test closer to the desired size at the expense of power. Our choice for the parameter compromises between size and power, as recommended by Kwiatkowski, Phillips, Schmidt, and Shin (1992). However, given the power problems associated with the ADF test (see Kremers, Ericsson and Dolado (1992)), in making this compromise we were more willing to sacrifice power and chose a relatively large value for the lag truncation parameter to remain evenhanded with respect to the ADF test..
} 
Given these conclusions, in subsequent sections we treat real exchange rates and real interest rates as I(1) variables and real interest differentials as $I(0)$ variables. Although not consistent with every test result in Table 1, these assumptions seem reasonable.

\section{Framework}

The parity conditions we use suggest a strong relationship between real exchange rates and real interest rate differentials. This section reviews these parity conditions and describes three alternative assumptions used in our empirical implementation.

\subsection{Definitions and Basic Relationship ${ }^{11}$}

Uncovered interest rate parity condition (UIP) links expected movements in the exchange rate to nominal interest rates at any horizon. Nominal UIP is defined as follows: ${ }^{12}$

$$
s_{t}-E_{t}\left[s_{t+j}\right]=\frac{j}{4} \cdot\left(i_{t, t+j}-i_{t, t+j}^{*}\right)
$$

where

$$
\begin{aligned}
s_{\mathrm{t}}= & \text { natural logarithm of the spot exchange rate (foreign currency per dollar) at time } t . \\
E_{\mathrm{t}}[.]= & \text { Expectations operator, conditional on information available at time } t . \\
i_{\mathrm{t}, j}= & \text { time } \mathrm{t} \text { yield to maturity (annualized) on U.S. pure discount bond maturing at time } \\
& \mathrm{j} \text {, expressed as a decimal. } \\
= & \text { time } \mathrm{t} \text { yield to maturity (annualized) on foreign pure discount bond maturing at } \\
& \text { time } \mathrm{j} \text {. expressed as a decimal. } \\
\mathrm{j}= & \text { forecast horizon, measured in quarters }
\end{aligned}
$$

Note that the maturity of the interest rate affects the coefficient on the interest rate differential. For example, with a 10 -year horizon the coefficient should equal $10(j / 4=40 / 4)$.

Next, the real exchange rate is defined as

$$
q_{t} \equiv s_{t}+p_{t}-p_{t}^{*}
$$

where

$$
\begin{aligned}
& \mathrm{p}_{\mathrm{t}} \quad=\text { natural logarithm of the consumer price index for the U.S. }\left(\mathrm{P}_{\mathrm{t}}\right. \text { the level) } \\
& \mathrm{p}_{\mathrm{t}}^{*} \quad=\text { natural logarithm of the consumer price index for the foreign country }\left(\mathrm{P}_{\mathrm{t}}^{*}\right. \text { the level). }
\end{aligned}
$$

\footnotetext{
${ }^{11}$ See Isard (1982) for the first complete accounting framework.

${ }^{12} \mathrm{We}$ implicitly assume that there is no risk premium.
} 
Using the real exchange rate definition from equation (2) to replace $s_{t}$ and $E_{t}\left(s_{t+j}\right)$ in equation (1) gives

$$
q_{t}=E_{t}\left[q_{t+j}\right]+\left(\frac{j}{4} \cdot i_{t, t+j}-\left(E_{t}\left[p_{t+j}\right]-p_{t}\right)\right)-\left(\frac{j}{4} \cdot i_{t, t+j}^{*}-\left(E_{t}\left[p_{t+j}^{*}\right]-p_{t}^{*}\right)\right)
$$

Defining the annualized inflation rate for the period $t$ to $t+j$ (given a quarterly frequency) and using the approximation that $\ln (1+x) \approx x$, inflation can be written as

$$
\pi_{t, t+j}=\left(\frac{P_{t+j}}{P_{t}}\right)^{\frac{4}{j}}-1 \cong\left(\frac{4}{j}\right) \cdot\left(p_{t+j}-p_{t}\right),
$$

Using equation (4) to replace terms in equation (3) gives

$$
q_{t}=E_{t}\left[q_{t+j}\right]+\frac{j}{4} \cdot\left(i_{t, t+j}-E_{t}\left[\pi_{t, t+j}\right]\right)-\frac{j}{4} \cdot\left(i_{t, t+j}^{*}-E_{t}\left[\pi_{t, t+j}^{*}\right]\right)
$$

Finally, by definition:

$$
q_{t}=E_{t}\left[q_{t+j}\right]+\frac{j}{4} \cdot\left(r_{t, t+j}-r_{t, t+j}^{*}\right)
$$

where $r_{t, t+j}$ is the real rate of interest. Equation (6) is a general statement about the relationship between real exchange rates and real interest rates or real uncovered interest parity (RUIP). At this point it is assumed that uncovered interest rate parity holds without error and that inflation is low enough to make the inflation approximation valid. Note, as above, that the coefficient on the real interest differential $(j / 4)$ varies with the length of the horizon considered.

\subsection{Implementation of RUIP Relationship}

The implementation and hence the interpretation of the empirical tests depends crucially on our treatment of the expected real exchange rate in equation (6). The rest of this section presents three different treatments, labelled standard, standard with additional variables, and ex post.

\subsubsection{Standard}

The first case, which is the most restrictive, assumes that the expected real exchange rate is constant $\left(\mathrm{E}_{\mathrm{t}} \mathrm{q}_{\mathrm{t}+\mathrm{j}}=\mathrm{C}\right)$. As pointed out by Meese and Rogoff $(1988)$, this is a crucial assumption which has been embodied for long horizons in the models of Dornbusch (1976) and Frankel (1979). Hence we refer to this case as the standard approach. The Dornbusch and Frankel models assume that goods market prices adjust slowly in response to disturbances, allowing temporary deviations of the 
real exchange from its long-run equilibrium value. The assumption of a constant expected real exchange rate reduces equation (6) to

$$
q_{t}=C+\frac{j}{4} \cdot\left(r_{t, t+j}-r_{t, t+j}^{*}\right)
$$

Many researchers have made the assumption of a constant real long-run expected exchange rate when testing the real interest rate parity condition, see for example, Meese and Rogoff (1988), Edison and Pauls (1993), and Baxter (1994). Nevertheless, the assumption of a constant expected real exchange rate can be criticized given the time series behavior of the real exchange rate (see among many others Froot and Rogoff (1995)). For example, the 'constant' assumption is inconsistent with our finding of a nonstationary real exchange rate in section 2. However, recent evidence of reversion towards purchasing power parity over long time periods (see among others Edison, Gagnon, and Melick (1994) and Frankel and Rose (1995)) may lend some credence to the assumption for suitably long horizons. Therefore, even though we know that this assumption is questionable, this approach will receive considerable attention in our paper since it has been so prominent in the literature.

\subsubsection{Standard with Additional Variables}

The second case relaxes the assumption that the expected real exchange rate is constant. Instead it posits that the expected real exchange rate can be modelled using additional variables. In this instance equation (6) becomes

$$
q_{t}=q(.)+\frac{j}{4} \cdot\left(r_{t, t+j}-r_{t, t+j}^{*}\right)
$$

where $\mathrm{q}($.$) is a function of additional variables. This approach was first considered by Hooper and$ Morton (1982), who modelled the expected real exchange rate as a function of the cumulated current account. The advantage of this approach is that the expected long run real exchange rate is not some constant value, but rather takes on some stochastic properties. This approach has been reasonably popular; see for example Blundell-Wignall and Browne (1991), Johansen and Juselius (1992), and Chinn (1995). Although, it has been only moderately successful in establishing a link between the real exchange rate, the cumulated current account, and the real interest rate, this approach will be adopted here.

\subsubsection{Ex Post}

An alternative to the approaches described above would be to substitute ex post values and forecast errors for the expected real exchange rate: 


$$
\begin{gathered}
-9- \\
E_{t}\left[q_{t+j}\right]=q_{t+j}+\lambda_{t}
\end{gathered}
$$

Making the substitution from equation (9) into equation (6), and combining error terms yields

$$
q_{t}=q_{t+j}+\frac{j}{4} \cdot\left(r_{t, t+j}-r_{t, t+j}^{*}\right)+\lambda_{t}
$$

This approach, to the best of our knowledge, has not been investigated by other researchers, perhaps because its use of the ex post real exchange rate severely limits the available data sample. Even after twenty years of floating rates, consideration of the ex post approach under a long term horizon eliminates roughly $1 / 3$ of our data sample.

\section{Empirical Results}

This section presents the estimation results for our three approaches. For each approach, the choice of estimation technique was guided by the unit root test results found in section 2 .

\subsection{The Standard}

The standard approach is represented by equation (7), which relates the level of the real exchange rate (or deviations of the real exchange rate from its constant expectation) to the real interest differential. Figure 4 presents plots of the real exchange against the real interest differential across currencies and horizon. None of the plots convincingly suggests a strong link between the real exchange rate and real interest differential. However, the plots for the German mark and the tradeweighted dollar at the long-horizon appear to suggest that the two time series might be correlated. Notice that the lowest left panel reproduces Figure 1, except the right-hand scale in Figure 1 is a logarithmic ratio scale, while the scale in Figure 2 is not. This difference in scaling explains in part the lack of strong apparent co-movement. Another striking point is that the strongest relationship appears for the German mark, whereas there appears to be little relationship between the other two bilateral exchange rates and their real interest differentials. All in all, these graphs seem to suggest that the strong relationship between real exchange rates and real interest rates displayed in Figure 1 may be tenuous.

Given the stationarity properties of the data (outlined in Section 2) we interpret equation (7) as specifying a particular functional form for a cointegrating vector involving the real exchange rate and real interest rates. Based on Section 2 we are assuming that the real exchange rate is I(1). Therefore 
for equation (7) to be balanced in a time series sense, the right hand side must also be I(1). Again based on Section 2, this will be the case if the real interest rates are included separately and not as a real interest differential. In the event that a cointegrating vector is found, hypothesis testing must be used to ensure that the vector involves more than just a real interest differential and that it is consistent with equation (7). In the remainder of the section we use the Johansen procedure to first search for a cointegrating vector and then conduct hypothesis tests about its form.

\subsubsection{Testing for Cointegration}

In brief (see Johansen (1991) for a fuller description), the Johansen procedure analyzes the relationship among p quarterly $\mathrm{I}(1)$ or $\mathrm{I}(0)$ variables using the following VAR system:

$$
\Delta X_{t}=\Gamma_{1} \Delta X_{t-1}+\ldots+\Gamma_{k-1} \Delta X_{t-(k-1)}+\Pi X_{t-k}+\mu+\eta D_{t}+\varepsilon_{t}
$$

$\boldsymbol{X}_{\mathrm{t}}$ is a $(\mathrm{p}, 1)$ vector of observations on the $\mathrm{p}$ variables at time $\mathrm{t}$. For our application $\mathbf{X}_{\mathbf{t}}=\left(\mathbf{q}_{\mathbf{t}}, \mathbf{r}_{\mathbf{t}}, \mathbf{r}_{\mathbf{t}}{ }^{*}\right)$. $D_{t}$ is a $(3,1)$ matrix of centered, seasonal dummies, $\mu$ is a $(p, 1)$ vector of constant terms for each equation, and $\varepsilon_{t}$ is a $(\mathrm{p}, 1)$ vector of error terms. $\Gamma$ and $\Pi(\mathrm{p}, \mathrm{p})$ and $\eta(\mathrm{p}, 3)$ are matrices of coefficients.

The long-run relationships in the data set are captured in the $\Pi$ matrix. If the rank of $\Pi$ is between 0 and $\mathrm{p}$, (denoted $\mathrm{z}$ ), then there are $\mathrm{z}$ linear combinations of the variables in the system that are $\mathrm{I}(0)$ (cointegrated). In this situation, $\Pi$ can be decomposed into two $(\mathrm{p}, \mathrm{z})$ matrices $\alpha$ and $\beta$ such that $\Pi=\alpha \beta$ ' where $\beta$ contains the coefficients of the cointegrating vectors and $\alpha$ is the matrix of coefficients on the cointegrating vectors (speed-of-adjustment coefficients) in each equation.

Johansen (1991) presents two tests for determining the rank of $\Pi$, the "trace" test, and the "maximum eigenvalue" test. Johansen and Juselius (1990) present tables of asymptotic critical values for the two test statistics. In addition, Johansen (1991) demonstrates that tests of restrictions on the coefficients of $\beta$ have chi-squared asymptotic distributions.

We include two wrinkles to the standard Johansen setup embodied by equation (11): first we add an additional dummy variable to the equation to account for the runup in interest rates (see Figure 3) during the initial Volcker inflation fighting days (1979Q4 - 1982Q4), and second, we assume a constant in the cointegrating vector, as in equation (7). ${ }^{13}$ We estimate equation (11) with $\mathrm{k}$ set equal

\footnotetext{
${ }^{13}$ Notice in the lower right-hand panel in figure 3 that the runup in U.S. real short-term interest rate was briefly interrupted by a sharp drop in the short term nominal rate.
} 
to two, after confirming that this choice for $\mathrm{k}$ left the residuals in equation (11) consistent with serially uncorrelated Gaussian disturbances. ${ }^{14}$

Table 2 reports our results for the long-term horizon. Using the trace tests (row TT) and strictly applying the asymptotic critical values with a test size of 5 percent, only the trade-weighted value of the dollar has a significant cointegrating vector (TT> 34.79). If, however, one uses the test size of 10 percent then Germany, Japan, and the trade-weighted dollar have one significant cointegrating vector (TT>31.88). We identify the same currencies when we use the maximum eigenvalue test (row MT). Thus, at the 10 percent level, three of the four exchange rates exhibit a single coiritegrating vector, a result consistent with equation (7). ${ }^{15}$

The search for a cointegrating vector at the short-term horizon yields a more definitive result, as can be seen in Table 3. For all four currencies we cannot reject the hypothesis that there is no cointegrating vector at the five percent level. The results for both the trace (Row TT) and the maximum eigenvalue (Row MT) are consistently low, establishing the absence of a cointegrating vector, a similar result to that of Meese and Rogoff (1988). At the ten percent level, only for the trade-weighted dollar can we reject the hypothesis that there is no cointegrating vector. The lack of a cointegrating vector at the short-term horizon between the three variables is not surprising, given the assumption needed to derive equation (7). While market participants might have an unchanging expectation for the real exchange rate over a long horizon, perhaps based on purchasing power parity, it is less likely that they will have an unchanging expectation for the real exchange rate over a threemonth horizon. If this is the case, equation (7) is misspecified for the short-term horizon, and its failure at this horizon should not come as a surprise. However, given the significant ADF tests and the insignificant KPSS tests for the short-term standard interest differentials in Table 1, we are somewhat surprised that the Johansen procedure did not find a cointegrating vector. ${ }^{16}$

\footnotetext{
${ }^{14}$ Tests for this consistency and all subsequent estimates with the Johansen procedure were done with CATS in RATS version 1.0 (see Juselius and Hansen (1995)).

${ }^{15}$ However, implementation of the Johansen procedure is complicated by our small sample size (79 observations). Edison, Gagnon, and Melick (1994) in an application to PPP generate small-sample corrections to the trace and maximum eigenvalue. Following their methodology we calculate finite sample critical values (see their paper for details.). For the trace test, these critical values are 35.3 and 38.6 respectively for the 10 and 5 percent size test. Notice that using these critical values makes it more difficult to find a cointegrating vector. In fact, in this instance none of the countries appear to have a cointegrating vector. This finding qualifies the asymptotic results, leaving only moderate evidence of a cointegrating vector at the long-term horizon.

${ }^{16}$ The conflict between the univariate (Table 1) and the multivariate (Table 3) cointegration findings may stem from the short length of the time series involved or from the "noisy" nature of the real interest differential.
} 


\subsubsection{Coefficient Restrictions on the Cointegrating Vector}

Thus far we have some evidence of a cointegrating vector only at the long horizon, and in this instance for three of the four exchange rates examined. However, we have yet to determine if the form of the cointegrating vector is in agreement with equation (7). We now turn our attention to this issue. The presence of a single cointegrating vector means that a linear combination of the real exchange rate, the real interest rates, and a constant term is $I(0)$. We write this as

$$
\beta_{1} q_{t}+\beta_{2} r_{t, t+j}+\beta_{3} r_{t, t+j}^{*}+\beta_{4}(C, q(.)) \sim I(0)
$$

where $\beta_{4}$ is multiplied by either $C$ a vector of ones, which is used in this section, or $q($.$) a vector of$ additional variables which is used in section (4.2). Under RUIP with a long-term horizon the coefficients of the cointegrating vector $\beta$, including the constant term, should be on the order of $\beta=$ $(1,-7,7, C)$ when the coefficient on the real exchange rate has been normalized to one. The rows labelled $\beta_{2}$ and $\beta_{3}$ in Table 2 for the trade-weighted dollar are close to those suggested by equation (7). In addition, exponentiation of the negative of the $\beta_{4}$ coefficient gives an estimate of the logarithm of the constant expected real exchange rate. For the mark, yen, and trade-weighted dollar these estimates are, respectively, 20.91, 25.53, and 92.76. Comparing these values to the plots of the real exchange rate in Figure 2, the estimates seem far too low for mark and yen but quite reasonable for the trade-weighted dollar. However, formal tests of the coefficient restrictions are to be preferred to qualitative comparisons.

Within the Johansen procedure it is possible to formally test restrictions on the coefficients of a cointegrating vector. For the three countries where a cointegrating vector seems somewhat likely we test the following hypotheses concerning equation (12).

- The coefficients on the interest rates have equal and opposite sign $\left(\beta_{2}=-\beta_{3}\right)$, as suggested by equation (7).

- The cointegrating vector involves only a linear combination of the real interest rates $\left(\beta_{1}=\right.$ $0)$. Note a special case would be that $r-r^{*}$ is $I(0)$.

Results for the first test are found in rows RE1-TS1 of Table 2. These rows present the largest eigenvalue under the restriction (for comparison to the row labelled $E$ ), the coefficients from the cointegrating vector under the restriction $\left(\beta_{3}\right.$ constrained to equal $\left.-\beta_{2}\right)$, and the value of the test statistic of the restriction. For the mark and trade-weighted dollar the test of the restrictions cannot be 
rejected at the five percent level using asymptotic critical values (TS1<3.84). ${ }^{17}$ If we use adjusted critical values, then even for Japan we cannot reject the restriction implied by equation (7). Two features of the coefficients on the restricted cointegrating vectors are worthy of mention. First, for all currencies, the coefficient on the real interest differential $\left(\beta_{2}\right.$ or $\left.-\beta_{3}\right)$ is quite close to that in equation (7). Second, for the mark and yen, the estimate for the constant expected real exchange rate (exp(- $\left.\beta_{4}\right)$ ) now seems much more in line with Figure 2 (113.30 and 59.15 respectively).

The positive results from this first test must be tempered by one possibility. It may be the case that the cointegrating vector simply involves a linear combination of the real interest rates, perhaps the real interest differential as suggested by the KPSS results in the top panel of Table $1 .^{18}$ If so, the positive findings from the first test may be spurious in the sense that the real exchange rate is not truly a component of the cointegrating vector. Results for this hypothesis $\left(\beta_{1}=0\right)$ are found in the rows labelled RE2 and TS2 in Table 2 . For the mark and yen the hypothesis cannot be rejected using asymptotic critical values (TS2<3.84), while it is rejected for the trade-weighted dollar. Using adjusted critical values, the hypothesis cannot be rejected for any of the three currencies. Therefore, the cointegrating vector for the three currencies may well only involve real interest rates, having nothing tc do with the relationship found in equation (7).

Given the above test results, we reach the following conclusions. There is moderate evidence of a cointegrating vector between the real exchange rate and the real interest differential at a long horizon for the mark, yen, and the trade-weighted dollar. These cointegrating vectors are consistent with the formulation found in equation (7), especially for the trade-weighted dollar. However, there is some chance, especially for the mark and yen, that the cointegrating vector simply involves real interest rates and does not suggest a relationship between the real exchange rate and real interest rate differentials.

\subsection{Standard with additional variables}

Some studies have shown that the inclusion of additional variables such as the cumulated current account (scaled by GDP) are necessary to establish a relationship or to find better fitting

\footnotetext{
${ }^{17}$ To gauge the effects of sample size, another Monte Carlo experiment was conducted,in which the data generating process (DGP) contained a cointegrating vector with coefficients $(1,-10,10, c)$. The finite critical values are much larger than the standard asymptotic one, which means the asymptotic ones lead to more rejections. For example, the asymptotic critical values are 5.99/4.61 at the 5/10 percent level and for the finite sample critical values are 26.89/24.35.
}

${ }^{18}$ See also Gagnon and Unferth (1993) 
equations. For the three bilateral exchange rate equations, we re-estimate equation (11) having included the variable: the difference (United States - foreign) of the ratio of cumulated current account to GDP. Note that we do not augment completely $\mathbf{x}_{\mathbf{t}}$ but rather we treat the cumulated current account variable as weakly exogenous, including it in the cointegrating space and in current and lagged differences in the short-run dynamics.

Table 4 reports these expanded Johansen results. The inclusion of the cumulated current account variable dramatically increases the eigenvalue (Row E) for Canadian dollar (from .1 to .24). Using the trace tests (Row TT) and applying asymptotic critical values (TT>29.4) it appears that both the yen and Canadian dollar have one cointegrating vector. However, for the mark, it seems as though there might be two cointegrating vectors. But, under RUIP there should be only one cointegrating vector. In the subsequent hypothesis testing we assume there is only one cointegrating vector.

We now turn our attention to determining the form the cointegrating vector takes. As in section 4.1.1 we test multiple hypotheses by using equation (12) and the assumption that $\beta_{4}$ is the coefficient on $q($.$) . Specifically we test the following restrictions:$

- The cumulated current account should be excluded in the long run, $\beta_{4}=0$. (TS1)

- The coefficients on the interest rates have equal and opposite sign $\left(\beta_{2}=-\beta_{3}\right)$, as suggested by equation (7) (TS2).

- The cointegrating vector involves only a linear combination of the real interest rates $\left(\beta_{1}=\right.$ $0)$. Note a special case would be that $r-r^{*}$ is I(0) (TS3).

Results for the first test are found in row TS1, which contains the value of the test statistic of the exclusion restriction. For each currency we reject the exclusion of the cumulated current account differential using asymptotic critical values (TS1<3.84). This result suggests that those in Table 2 might be misspecified, as the cumulated current account is excluded in those estimated equations and it appears to be statistically significant. ${ }^{19}$

Next we test the RUIP hypothesis following the same testing procedure we used previously. The row TS2 gives the value of the test statistic when the coefficients from the cointegrating vector are to be $\beta_{2}=-\beta_{3}$. For Canadian dollar, we cannot reject the null hypothesis of the equal but opposite sign on the interest rates using the asymptotic critical values (TS2<3.84). In contrast to the results in

\footnotetext{
${ }^{19}$ On the other hand, it seems that the addition of this current account variable at least the way we have included it, dramatically changes the statistical properties of the residuals. Many of the diagnostic statistics suggest there is misspecification (See CATS in RATS ).
} 
Table 2, we now reject this hypothesis for the yen and mark. This finding suggests the specification of additional variables might be less informative than previously thought. The last test we consider (Row TS3), involves testing whether the interest rate differential alone forms the cointegrating vector. For all the currencies, we reject the null hypothesis, however for the mark and Canadian dollar these results are quite weak.

In general, the results for simply including the cumulated current account are mixed. It seems as though it might contribute to the model, but it also seems to introduce misspecification as indicated by the residuals. ${ }^{20}$

\subsection{Ex Post}

Rather than assuming that the expected value of the real exchange rate is constant or that it is a function of additional variables, the ex post approach substitutes ex post values and forecast errors for the expected real exchange rate. If market participants form unbiased expectations of the real exchange rate, the ex post approach should uncover a close relationship between dollar depreciation and the interest differential. Equation (10) provides the functional form for testing the ex post approach. Based on the unit root tests reported in Section 2. we assume that ex post real dollar depreciation $\left(q_{t}-q_{t+j}\right)$ and real interest differentials $\left(r_{t, t+j}-r_{t, t+j}^{*}\right)$ are stationary. Therefore no special econometric techniques such as the Johansen procedure are required to allow for nonstationary variables.

Plots of ex post depreciation and the real interest differential for the currency/horizon pairs are found in Figure 5. Note that the long-term horizon $(j=28$ in equation (10)) leads to a much smaller sample size, trimming 7 years worth of observations off the end of the sample. The plots suggest that a relationship is most likely to be found, after allowing for a lag, at the long-term horizon rather than the short-term horizon. Among the currencies, the Canadian dollar and its associated interest differential have moved over a much narrower range during the period.

To investigate formally the relationship between ex post dollar depreciation and the real interest differential we use a general to specific modelling approach. The following Autoregressive Distributed Lag (ADL) regression was estimated for each currency/horizon pair,

\footnotetext{
${ }^{20}$ We make one further attempt at this approach by considering both cumulated current account variables and the change in the price of oil. The change in the price of oil has been shown by Johansen and Juselius (1992) to be quite important in their efforts in explaining the effective British pound sterling. Following Johansen and Juselius, we add the change in the price of oil to the equation (11), by including it in the short-run dynamics but not in the cointegration space. The results for including the change in the price of oil along with the cumulated current are essentially the same, therefore, for brevity they have been excluded.
} 


$$
q_{t}-q_{t+j}=\kappa+\sum_{i=1}^{5} \gamma_{i}\left(q_{t-i}-q_{t+j-i}\right)+\sum_{i=0}^{5} \lambda_{i}\left(r_{t-i, t+j-i}-r_{t-i, t+j-i}^{*}\right)+\delta D_{t}+\varepsilon_{t}
$$

where $D_{t}$ is a set of dummy variables containing the Volcker dummy described in Section 4.1, and a set of uncentered, quarterly dummies. For the long-term horizon, the overlap of periods of $e x$ post depreciation will generate a moving average process in the error term of equation (13). We use the methods of Hansen (1982) to correct for this moving average and generate a consistent estimate of the covariance matrix. For each horizon/currency pair, the specification in equation (13) passed a battery of mis-specification tests for all currency/horizon pairs. ${ }^{21}$ Insignificant coefficients were eliminated from equation (13) following the general to specific approach, after verifying that the reductions passed the F-test for coefficient elimination and that the resulting equation continued to satisfy the battery of diagnostic tests. Summary results that focus on the contribution of the real interest differential from the final, "specific" specifications are shown in Table $5 .^{22}$

For each currency/horizon pair in table 5, three results are displayed. First, the long-run coefficient on the real interest differential, calculated as $\Sigma \lambda /(1-\Sigma \gamma)$. Second, an F-test on the joint significance of the $\lambda \mathrm{s}$, and third the largest (in absolute value) $\gamma$. These three measures are meant to convey, in turn,

- the extent to which the real interest rate differential influences the exchange rate as suggested by equation (10)

- whether the influence of the real interest rate differential is significant in a statistical sense

- some notion of the extent to which ex post depreciation depends on its own past.

The results in Table 5 have a straightforward interpretation and confirm the impressions formed from Figure 5. With the exception of the yen, at the short-term horizon there does not appear to be a significant relationship between real ex post depreciation and the real interest differential. For the Canadian dollar, mark, and trade-weighted dollar, the long-run coefficient is insignificant and not close to the .25 suggested by equation (10). At the short-term horizon, only in the case of the yen is the coefficient significant and consistent with equation (10). However, even in this instance: the

\footnotetext{
${ }^{21}$ The battery of tests consisted of tests for autocorrelated, squared autocorrelated, non-normal, ard heteroscedastic residuals, as well as a heteroscedasticity/functional form test and a RESET test. Complete descriptions of these tests can be found in Doornik and Hendry (1994).

${ }^{22}$ Full estimation results are available upon request.
} 
significance is marginal. All in all, real ex post dollar depreciation does not appear related to the real interest rate differential over a short horizon.

At the long-term horizon there is a highly significant relationship between ex post depreciation and the interest differential for the mark and the trade-weighted dollar. Moreover, in both cases the long-run coefficient is close to the value of roughly seven suggested by equation (10). For the other two currencies (Canadian dollar and the yen) there is not a significant relationship. However, for the mark and the trade-weighted dollar the presence of a large autoregressive term is troubling. To the extent that the autoregressive term is proxying for unexplained determinants of the ex post dollar depreciation, the real interest differential is contributing little to our understanding of ex post depreciation. This appears to be the case for these two currencies. Excluding the real interest differentials from the equation only increased the standard error of the estimate for the mark and the trade-weighted dollar by 3.8 percent and 2.5 percent respectively.

In short, for the ex post approach, a relationship between expected dollar depreciation and the real interest differential only exists for the long-term horizon with the mark and trade-weighted dollar. In these instances, the coefficient on the real interest differential is on the order of that suggested by RUIP. However, although its effect is precisely estimated (significant in a statistical sense), the real interest differential does little to help our understanding of past exchange rate movements.

\section{Conclusion}

This paper examines the empirical relationship between real exchange rates and real interest rates using three approaches across four currencies and two horizons with data spanning over twenty years. Using the standard approach, assuming real exchange rates and real interest rates are I(1) variables, we find moderate evidence of a cointegrating vector at a long horizon and no evidence of a cointegrating vector at a short horizon. At the long horizon the cointegrating vector appears to be consistent with real uncovered interest parity, although it could also be consistent with just a linear combination of the two real interest rates that does not involve the real exchange rate. These results are more promising than some of the earlier studies which failed to identify the cointegrating vector. ${ }^{23}$

Using the standard approach with additional variables, we find stronger evidence of a cointegrating vector. However, we fail to establish that the cointegrating vector is consistent with real

\footnotetext{
${ }^{23}$ See, for example, Edison and Melick (1992).
} 
uncovered interest rate parity or that the interest rate differential is stationary. We are left with some uncertainty as to what is driving this relationship. This lack of uncertainty has been prevalent in this literature and might be the result of how we treated these additional variables.

Using the ex post approach, assuming that both ex post real dollar depreciation and the ex post real interest differential are $\mathrm{I}(0)$ variables, we find that the interest differential is significant in explaining dollar depreciation only at the long horizon. However, past dollar depreciation appears much more important than the interest differential in explaining dollar depreciation.

The goal of this paper was to investigate the empirical relationship between real exchange rates and real interest rates. We have put yet another nail in the coffin that this relationship does not hold at the short horizon. However, at the long horizon there does appear to be a link between real interest rates and real exchange rates. This relationship is most apparent for the trade-weighted dollar. Given that exchange rates and interest rates may well be determined simultaneously, it remains to be seen if the relationship could be exploited in forecasting or modelling the exchange rate. 


\section{Data Appendix}

All data are at a quarterly frequency (end of the quarter) covering the period 1971Q1 to $1994 \mathrm{Q} 4$. Series are listed below with the source in parenthesis. The trade-weighted calculations use the following weights in a geometric average: Germany (0.208), Japan (0.136), United Kingdom (0.119), Canada (0.091), Italy (0.09), Netherlands (0.083), Belgium (0.064), Sweden (0.042), Switzerland (0.036). (For further details on this see FRB Bulletin August 1978.)

\section{Exchange Rate}

Trade-weighted value of the dollar (FRB Bulletin).

Canadian dollar/U.S. dollar (FRB Bulletin).

German mark/U.S. dollar (FRB Bulletin).

Japanese y'en/U.S. dollar (FRB Bulletin).

\section{Interest Rates}

Short-Term

U.S three-month Treasury bills (FRB Bulletin).

Trade-weighted average on three-month interbank loans for foreign G-10 countries (various publications).

Canadian finance company paper (FRB Bulletin).

German three-month interbank loan rate. (FRB Bulletin)

Japanese CD rate (FRB Bulletin)

Long-Term

U.S ten-year constant maturity on Treasury bonds (FRB Bulletin)

Trade-weighted average yields on bellwether government bonds for foreign G-10 countries (various publications).

Cánadian bellwether government bonds (Bank of Canada Review).

German bellwether government bonds (Bundesbank Monthly Report).

Japanese bellwether government bonds (Tokyo Stock Exchange).

Prices (CPIs)

U.S. (FRB Bulletin)

Trade-weighted average for foreign G-10 countries (various publications).

Canada (Bank of Canada Review).

Germany (Bundesbank Monthly Report).

Japan (Bank of Japan, Economic Statistics).

\section{Current Account}

U.S. (FRB Bulletin)

Canada (Bank of Canada Review).

Germany (Bundesbank Monthly Report).

Japan (Japanese Economic Indicators, EPA).

(To obtain the cumulated current account we assume for each country that the cumulated current account was zero in 1971Q1 and accumulate the current account thereafter.) 
GNP

U.S. (FRB Bulletin)

Canada (Canadian Economic Observer).

Germany (Wirtschaft und Statistik).

Japan (Bank of Japan, Economic Statistics). 


\section{References}

Baxter, Marianne, 1994, "Real Exchange Rates and Real Interest Differentials: Have We Missed the Business Cycle Relationship?" Journal of Monetary Economics: 33, 5-37.

Blundell-Wignall, A. and F. Browne, 1991, "Increasing Financial Market Integration. Real exchange rates and Macroeconomic Adjustment," OECD Working Paper.

Campbell, J. Y. and R. H. Clarida, 1987, "The Dollar and Real Interest Rates," Carnegie-Rochester Conference Series on Public Policy, 24: (eds.) A. Meltzer and K. Brunner, North Holland: Amsterdam.

Coughlin, C. C. and K. Koedijk, 1990, "What Do We Know About the Long-Run Real Exchange Rate?," St Louis Federal Reserve Bank Review, Volume 72, No 1 January/February, 36-48.

Dickey, David A., and Wayne A. Fuller, 1979, "Distribution of the Estimators for Autoregressive Time Series with a Unit Root," Journal of the American Statistical Association, 74, 427-431.

Doornik, Jurgen A. and David F. Hendry, PcGive 8.0: An Interactive Econometric Modelling System, International Thomson: London.

Dornbusch, Rudiger, 1976, Expectations and Exchange Rate Dynamics," Journal of Political Economy, 8.4, 1161-76.

Edison, Halli J., Joseph E. Gagnon and William R. Melick, 1994, "Understanding the Empirical Literature on Purchasing Power Parity: The Post-Bretton Woods Era," International Finance Discussion Paper No. 465, Board of Governors of the Federal Reserve, Washington, DC, April.

Edison, He.li J. and William R. Melick, 1992, "Purchasing Power Parity and Uncovered Interest Rate Parity: The: United States 1974-1990, International Finance Discussion Paper No. 425, Board of Governors of the Federal Reserve, Washington, DC, March.

Edison, Hali J. and B. Dianne Pauls, 1993, "A Re-assessment of the Relationship Between Real Exchange Rates and Real Interest Rates: 1974-1990," Journal of Monetary Economics, 31, 165-187.

Faust, Jon, 1994, "Comparing the Long-Term Interest Rate Spreads using Coupon and Pure Discount Bonds," Federal Reserve Board, memo, May.

Frankel, Jeffrey A., 1979, "On the Mark: A Theory of Floating Exchange Rates Based on Real Interest Differentials," American Economic Review, 69, 610-622.

Frankel, Jeffrey A. and Andrew K. Rose, 1994, "A Survey of Empirical Research on Nominal Exchange Rates", in Handbook of International Economics: eds. Gene Grossman and Kenneth Rogoff.

Frankel, Jeffrey A. and Andrew K. Rose, 1995, "A Panel Project on Purchasing Power Parity: Mean Reversion "Within and Between Countries"

Fuller, Wayne A., 1976, Introduction to Statistical Time Series, New York: Wiley. 
Gagnon, Joseph G. and Mark D. Unferth, 1993, "Is There a World Real Interest Rate?" International Finance Discussion Paper No. 454, Board of Governors of the Federal Reserve, Washington, DC, forthcoming in the Journal of International Money and Finance.)

Hansen, Lars P., 1982, "Large Sample Properties of Generalized Method of Moments Estimators,"Econometrica, 50, 1029-1054.

Hansen, Henrik and Katarina Juselius, 1995, CATS in RATS: Cointegration Analysis of Time Series, Estima, Illinois.

Hooper, Peter and John Morton, 1982, "Fluctuations in the Dollar: A Model of Nominal and Real Exchange Rate Determination," Journal of International Money and Finance, 1, 39-56.

Hunter, John, 1992, "Tests of Cointegrating Exogeneity for PPP and Uncovered Interest Rate Parity in the United Kingdom," Journal of Policy Modelling: 14(4), 453-463.

Isard, Peter, 1982, "An Accounting Framework and Some Issues for Modelling How Exchange Rates Respond to the News," International Finance Discussion Paper No. 200 (Board of Governors of the Federal Reserve, Washington, DC).

Johansen, Søren, 1991, "Estimation and Hypothesis Testing of Cointegration Vectors in Gaussian Vector Autoregressive Models", Econometrica, 59, 1551-1580.

Johansen, Søren, and Katarina Juselius, 1990, "Maximum Likelihood Estimation and Inference on Co-integration - With Applications to the Demand for Money," Oxford Bulletin of Economics and Statistics, 52, 169-210.

Johansen, Søren and Katarina Juselius, 1992, "Testing Structural Hypotheses in a Multivariate Cointegration Analysis of the PPP and the UIP for UK," Journal of Econometrics: 53 pp 211-244.

Kremers, Jeroen, Neil R. Ericsson and Juan J. Dolado, 1992, "The Power of Cointegration 'Tests," Oxford Bulletin of Economics and Statistics, 54, 325-348.

Kwiatkowski, Denis, Peter C.B. Phillips, Peter Schmidt and Yongcheol Shin, 1992, "Testing the Null Hypothesis of Stationarity Against the Alternative of a Unit Root," Journal of Econometrics: 54, 159178.

Mark, Nelson C., 1995, Exchange Rates and Fundamentals: Evidence on Long-Horizon Predictability, American Economic Review, March, 85:1, 201-218.

Meese, R. A. and K. Rogoff (1988), "Was it Real? The Exchange Rate Interest Rate Relation, 1973-1984,"Journal of Finance, September, 43: 933-948.

Taylor, Mark, 1995, The Economics of Exchange Rates, Economic Literature, March, 33:1, 13-47. 


\begin{tabular}{|c|c|c|c|c|c|c|c|c|c|c|}
\hline \multicolumn{11}{|c|}{$\begin{array}{l}\text { Table 1: Statistical Properties of the Data } \\
\text { Augmented Dickey Fuller and KPSS Tests; 1974:Q1 - 1994Q4 }{ }^{1}\end{array}$} \\
\hline & \multicolumn{2}{|c|}{$q^{1}$} & \multicolumn{2}{|c|}{$r_{s}^{1,2}$} & \multicolumn{2}{|c|}{$\mathbf{r}_{\mathbf{L}}{ }^{3}$} & \multicolumn{2}{|c|}{$\left(r-r^{*}\right)_{s}^{1,2}$} & \multicolumn{2}{|c|}{$\left(r-r^{*}\right)_{L}^{3}$} \\
\hline & ADF & KPSS & $\mathrm{ADF}$ & KPSS & $\mathrm{ADF}$ & KPSS & ADF & KPSS & ADF & KPSS \\
\hline \multicolumn{11}{|l|}{ Standard } \\
\hline Canada & -1.666 & 0.269 & -1.974 & $0.671 *$ & -1.957 & $0.719 *$ & $-2.996^{*}$ & 0.355 & -1.913 & 0.34 \\
\hline Germany & -2.181 & 0.178 & -2.485 & $0.464 *$ & -1.986 & 0.375 & -2.785 & 0.135 & -2.731 & 0.386 \\
\hline Japan & -1.381 & $0.708 *$ & -1.972 & $0.563 *$ & $-3.564^{*}$ & $0.531^{*}$ & $-3.293^{*}$ & 0.15 & -2.781 & 0.101 \\
\hline Trade-weighted & -2.16 & 0.166 & -2.058 & $0.681^{\circ}$ & -2.199 & $0.787^{*}$ & -1.838 & $0.473^{\circ}$ & $-2.916^{*}$ & 0.151 \\
\hline United State; & -- & -- & -1.658 & 0.389 & -2.511 & 0.42 & -- & -- & -. & -- \\
\hline
\end{tabular}

1. The entire sample period is 1974 Q 1 to $1994 Q 4$.

2. The sample period for all tests involving trade-weighted short term interest rates is shorter: 1976Q3 to 1994Q4.

3. The sample period for standard long term interest rates is: 1974Q1 to 1993Q3.

* denotes significant at the 5 percent level. 
Table 2: Results from the Johansen Procedure using equation (11) k=2 1974:Q1 - 1993:Q3 Standard Measure of Long-Term Interest Rates

\begin{tabular}{|c|c|c|c|c|}
\hline \multicolumn{5}{|c|}{$\begin{array}{c}\text { Table 2: Results from the Johansen Procedure using equation (11) } k=2 \\
\text { Standard Measure of Long-Term Interest Rates }\end{array}$} \\
\hline & Canada & Germany & Japan & Trade-Weighted \\
\hline $\mathbf{E}$ & 0.1 & 0.2 & 0.27 & 0.25 \\
\hline $\mathbf{T T}$ & 16.46 & 34.87 & 33.49 & 35.64 \\
\hline MT & 8.58 & 17.29 & 25.07 & 23.06 \\
\hline$\beta_{1}$ & 1.00 & 1.00 & 1.00 & 1.00 \\
\hline$\beta_{2}$ & -23.98 & 10.2 & -6.9 & -8 \\
\hline $\boldsymbol{\beta}_{3}$ & 24.44 & -43.65 & -17.01 & 7.32 \\
\hline$\beta_{4}$ & -5.06 & -3.04 & -3.24 & -4.53 \\
\hline $\boldsymbol{\alpha}_{1}$ & 0 & 0.02 & 0 & -0.26 \\
\hline$\alpha_{2}$ & 0 & 0 & 0 & 0 \\
\hline$\alpha_{3}$ & 0 & 0 & 0 & 0 \\
\hline REl & na & 0.17 & 0.15 & 0.25 \\
\hline $\mathbf{R} \boldsymbol{\beta}_{1}$ & na & 1.00 & 1.00 & 1.00 \\
\hline $\mathbf{R} \boldsymbol{\beta}_{2}$ & na & -8.13 & -4.6 & -8.45 \\
\hline $\mathbf{R} \boldsymbol{\beta}_{3}$ & na & 8.13 & 4.6 & 8.45 \\
\hline$R \beta_{4}$ & na & -4.73 & -4.08 & -4.55 \\
\hline TS1 & na & 2.21 & 11.85 & 0.74 \\
\hline RE2 & na & 0.19 & 0.26 & 0.11 \\
\hline TS2 & na & 0.26 & 1.07 & 14.12 \\
\hline
\end{tabular}

Notes to Table:

$\mathbf{E}=$ Largest calculated eigenvalue

MT = Maximum Eigenvalue Test Statistic, Ho: non-cointegration

$\alpha_{1}=$ Adjustment coeff. for cointegrating vector in the e equation

$\alpha_{2}=$ Adjustment coeff. for cointegrating vector in the $r$ equation

$\alpha_{3}=$ Adjustment coeff. for cointegrating vector in the $r^{*}$ equation

REl $=$ Largest eigenvalue given restriction 1

TS1 = Test statistic for RUIP $\left(-\beta_{2}=\beta_{3}\right)$

* $\quad=$ Significant at 5 percent level

na $=$ not applicable
TT = Trace Test Statistic, Ho: non-cointegration

$\beta_{1}=$ First coefficient of the cointegrating vecto:

$\beta_{2}=$ Second coefficient of the cointegrating vector

$\beta_{3}=$ Third coefficient of the cointegrating vector

$\beta_{4} \quad=$ Constant in cointegrating vector

$R \beta=$ Restricted Beta coefficients

TS2 $=$ Test statistic for $\beta_{1}=0$

$+=$ Significant at 10 percent level 


\begin{tabular}{||l|l|l|l|l||}
\hline \multicolumn{2}{|c|}{ Table 3: Results from the Johansen Procedure using equation (11) k=2 1974:Q1 - 1994:Q4 } \\
Short-Term Interest Rates \\
\hline
\end{tabular}

Notes to Table:

' Sample 1976Q1 - 1994Q4

$\mathrm{E}=$ Largest calculated eigenvalue

TT $=$ Trace Statistic

MT = Maximum Eigenvalue Statistic 
Notes to Table:

E = Largest calculated eigenvalue

$\mathrm{MT}=$ Maximum Eigenvalue Test Statistic, Ho: non-cointegration

$\alpha_{1}=$ Adjustment coeff. for cointegrating vector in the e equation

$\alpha_{2}=$ Adjustment coeff. for cointegrating vector in the $r$ equation

$\alpha_{3}=$ Adjustment coeff. for cointegrating vector in the $\mathrm{r}^{*}$ equation

TS $1=$ Test statistic for exclusion of current account var. $\beta_{4}=0$

TS $3=$ Test statistic for $\beta_{1}=0$
Table 4: Results from the Johansen Procedure using equation (10) $k=2$ 1974:Q1 - 1993Q3

Long-Term Interest Rates and Cumulated Current Accont

\begin{tabular}{||l|l|l|l|}
\hline & \multicolumn{1}{|c|}{ Canada } & Germany & Japan \\
\hline $\mathrm{E}$ & 0.26 & 0.29 & 0.25 \\
\hline $\mathrm{TT}$ & 34.3 & 48.6 & 30.77 \\
\hline $\mathrm{MT}$ & 23.3 & 26.6 & 22.5 \\
\hline$\beta_{1}$ & 1.0 & 1.0 & 1.0 \\
\hline$\beta_{2}$ & 2.18 & -2.7 & -5.41 \\
\hline$\beta_{3}$ & -2.43 & -9.45 & 1.07 \\
\hline$\beta_{4}$ & -0.72 & -0.133 & -0.31 \\
\hline$\alpha_{1}$ & -0.98 & -0.126 & -0.23 \\
\hline$\alpha_{2}$ & -0.002 & 0.005 & 0.005 \\
\hline$\alpha_{3}$ & -0.004 & 0.027 & 0.006 \\
\hline TS 1 & 12.25 & 4.65 & 10.89 \\
\hline TS2 & 0.07 & 5.37 & 9.43 \\
\hline TS 3 & 4.36 & 4.65 & 12.69 \\
\hline
\end{tabular}

TT = Trace Test Statistic, Ho: non-cointegraticn

$\beta_{1}=$ First coefficient of the cointegrating vector

$\beta_{2}=$ Second coefficient of the cointegrating vector

$\beta_{3}=$ Third coefficient of the cointegrating vector

$\mathrm{C}=$ Constant in cointegrating vector

TS2 $=$ Test statistic for RUIP $\left(-\beta_{2}=\beta_{3}\right)$

- $=$ Significant at 5 percent level 


\begin{tabular}{|c|c|c|c|c|c|c|}
\hline \multicolumn{7}{|c|}{$\begin{array}{c}\text { Table } 5 \\
\text { Specific ADL Regression Results }\end{array}$} \\
\hline \multirow{2}{*}{$\begin{array}{l}\text { Country } \\
\end{array}$} & \multicolumn{3}{|c|}{$\begin{array}{r}\text { Short-Term Horizon } \\
(1974 Q 1-1994 Q 4)^{1}\end{array}$} & \multicolumn{3}{|c|}{$\begin{array}{c}\text { Long-Term Horizon } \\
(1974 Q 1-1988 Q 1)\end{array}$} \\
\hline & $\begin{array}{l}\text { Long-Run } \\
\text { Coefficient }\end{array}$ & F-Test & $\begin{array}{l}\text { Largest } \\
\text { AR } \\
\text { Term }\end{array}$ & $\begin{array}{l}\text { Long-Run } \\
\text { Coefficient }\end{array}$ & $\mathrm{X}^{2}$-Test & $\begin{array}{l}\text { Largest } \\
\text { AR } \\
\text { Term }\end{array}$ \\
\hline Canada & -0.13 & 0.42 & 0.29 & 6.76 & 0.58 & 1.23 \\
\hline Germany & 0.10 & 0.94 & na & 11.12 & $11.32^{* * *}$ & 0.88 \\
\hline Japan & 0.32 & $3.35^{*}$ & 0.30 & -7.44 & 0.95 & 1.24 \\
\hline $\begin{array}{l}\text { Trade- } \\
\text { Weighted }\end{array}$ & 0.001 & 0.00 & na & 11.53 & $9.56^{* *}$ & 1.18 \\
\hline
\end{tabular}

Notes to Table:

1. For the tradz-weighted dollar,at the short-term horizon, the sample begins in 1976Q4

Long-Run Coefficient $=$ Sum of real interest differential coefficients divided by one minus the sum of lagged ex post depreciation coefficients F-Test, $\mathrm{X}^{2}$-Test - Test of the restriction that all interest differential terms are insignificant. The long-run test is $\mathrm{X}^{2}$ due to the correction for moving average errors.

Largest AR Term - Largest (in absolute value) coefficient from a lagged ex post depreciation term.

* = significant at 5 percent level

** = significanl. at 1 percent level 


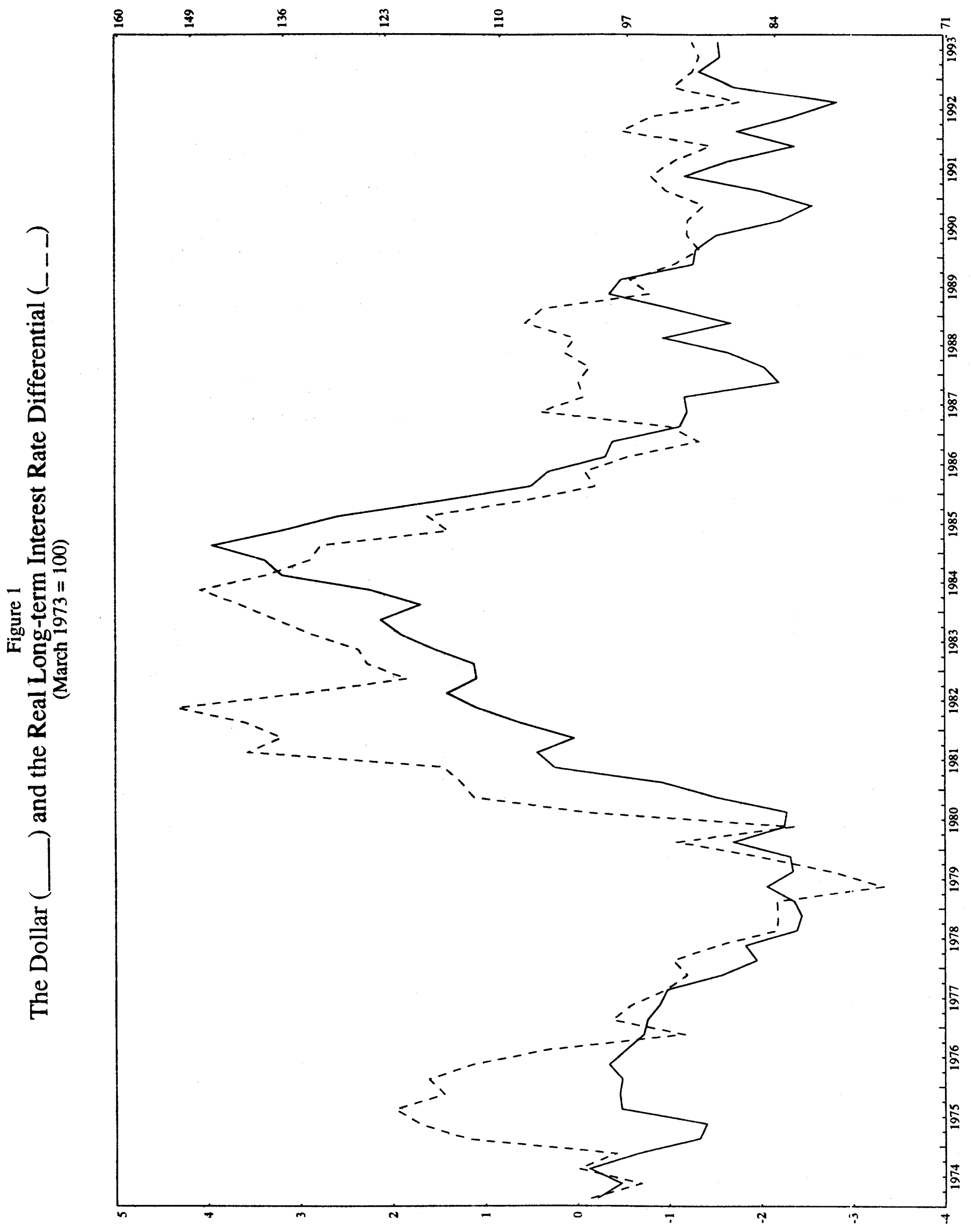


Figure 2

Real Exchange Rates

(Foreign Currency/U.S. Dollar, March 1973 = 100)

\section{Canadian Dollar}

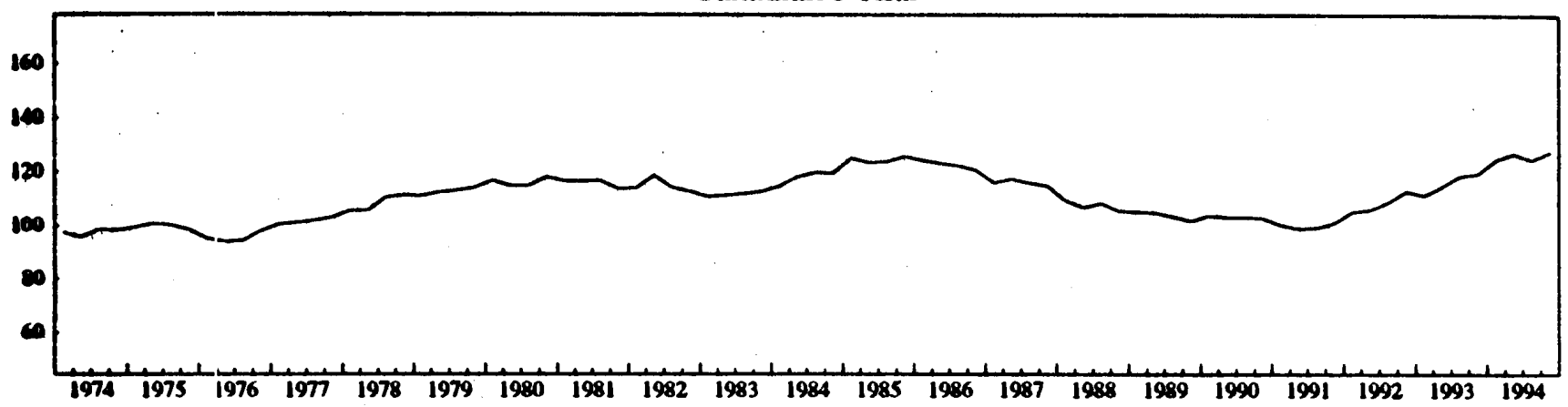

German Mark

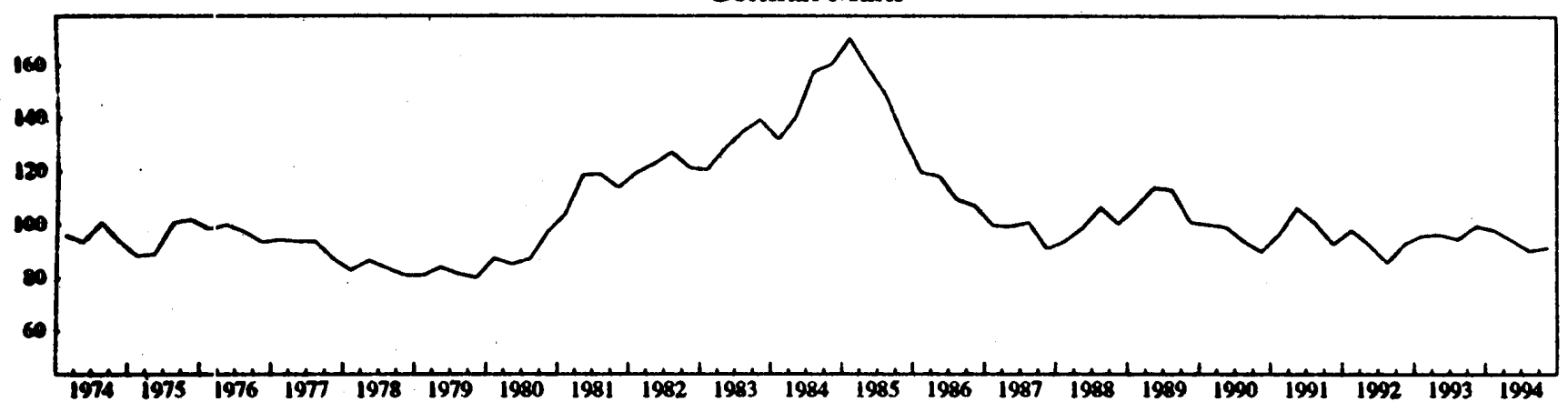

Japanese Yen

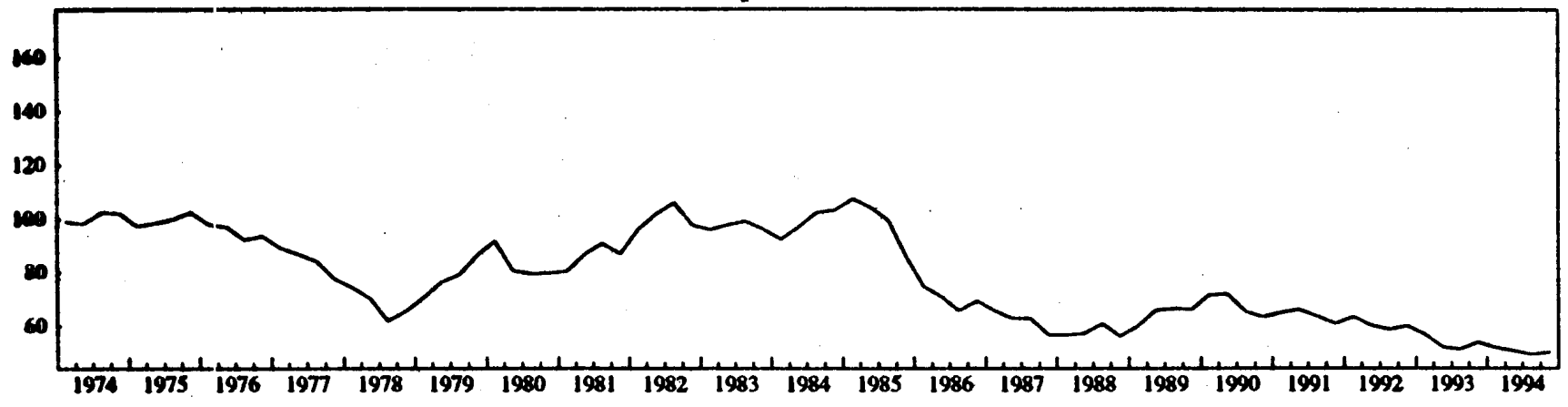

Trade-Weighted Dollar

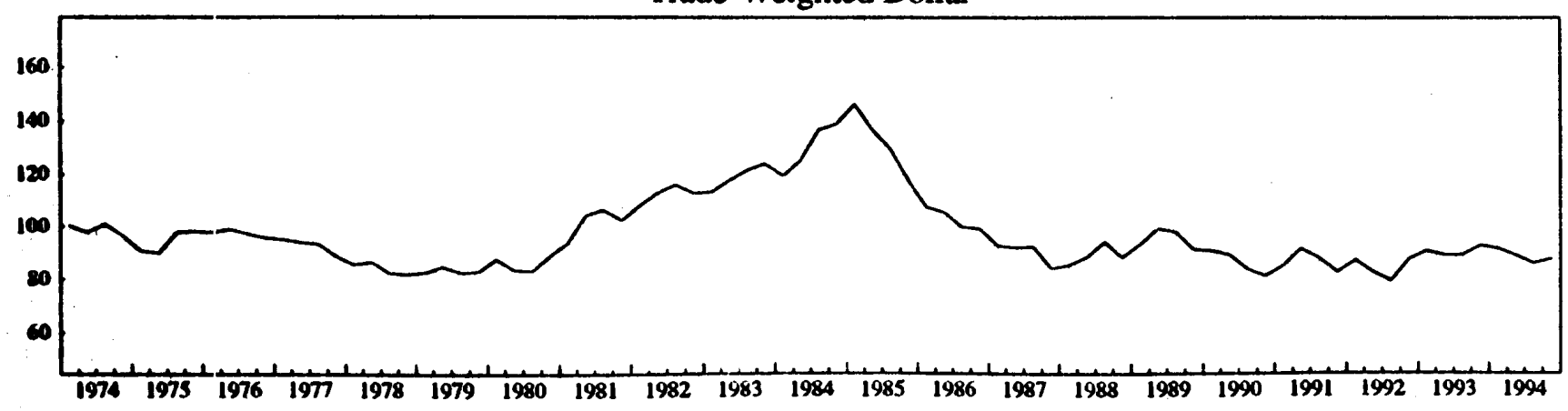


Figure 3

Real Interest Rates

Long-Term
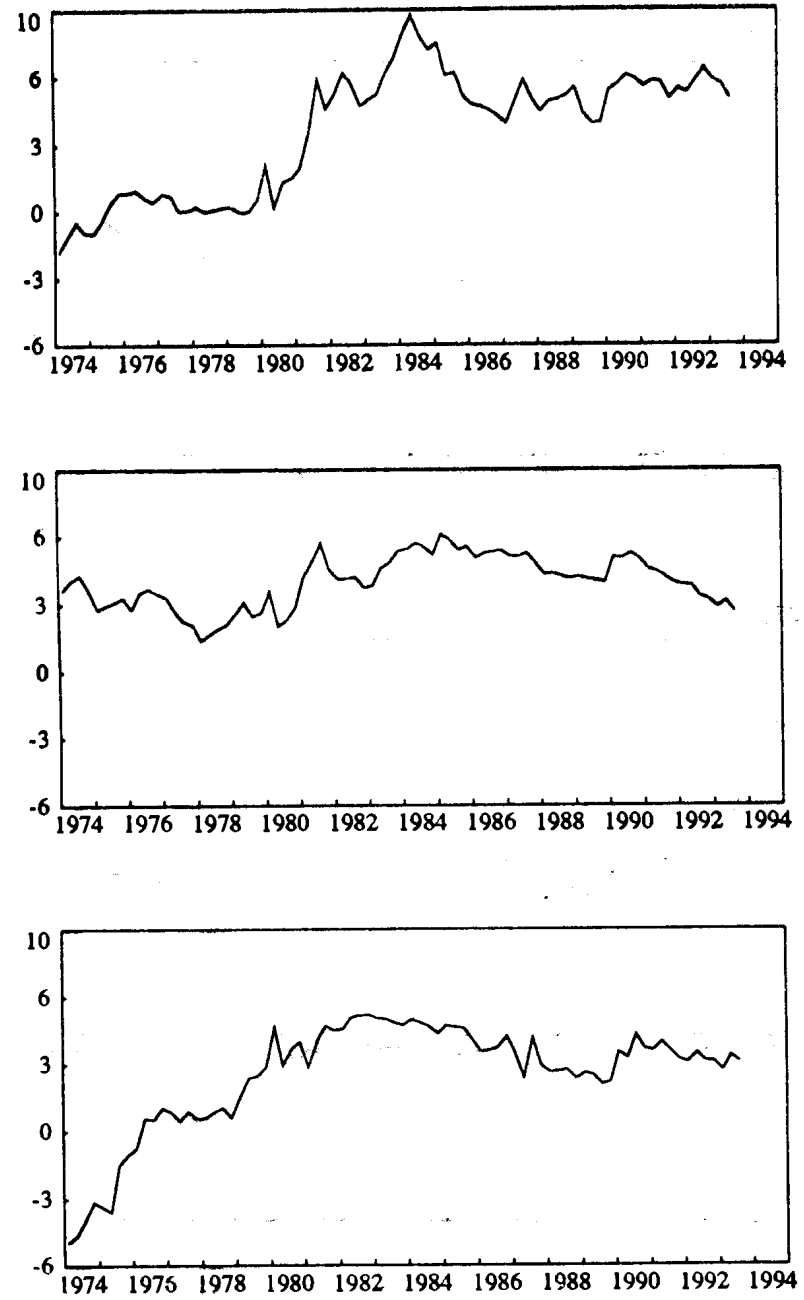

Trade-Weighted

\section{Short-Term}

\section{Canada}

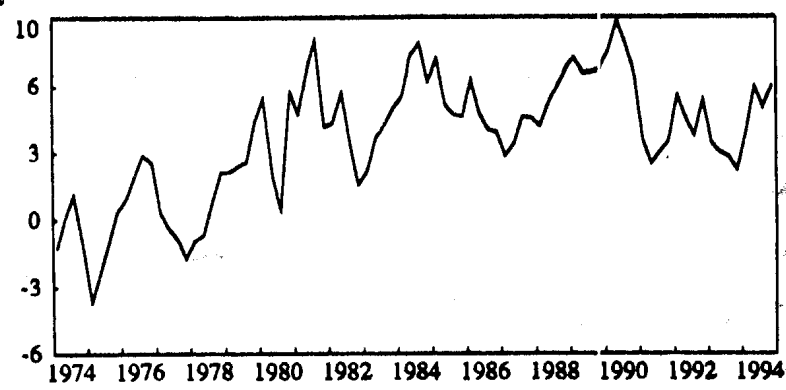

Germany

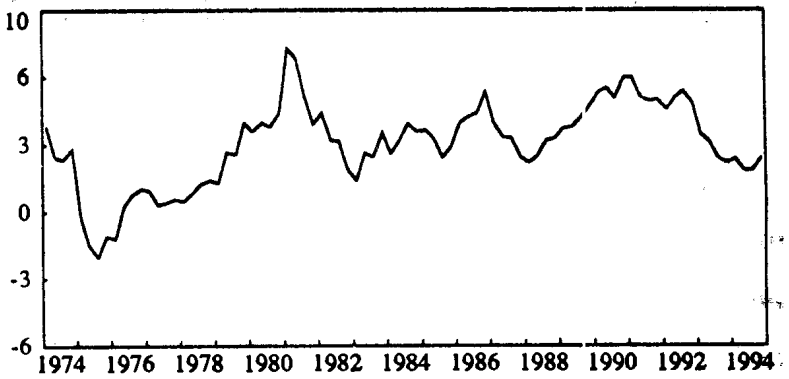

Japan

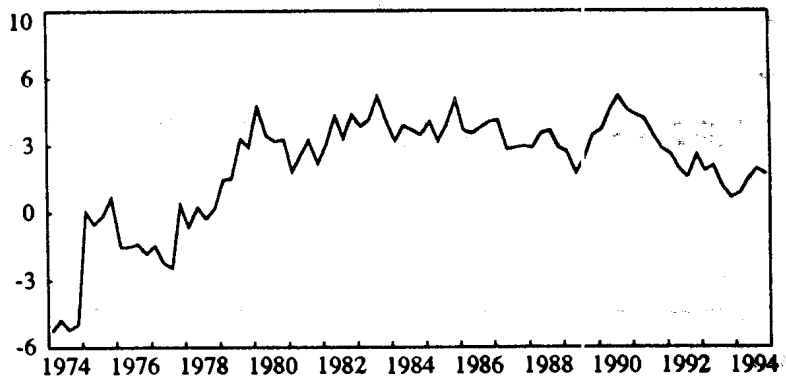

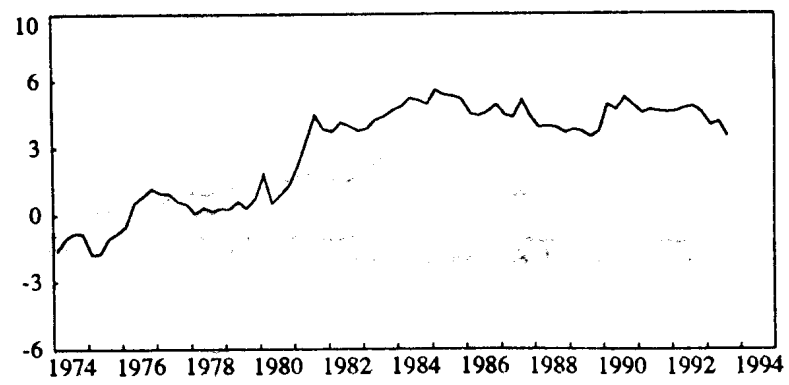

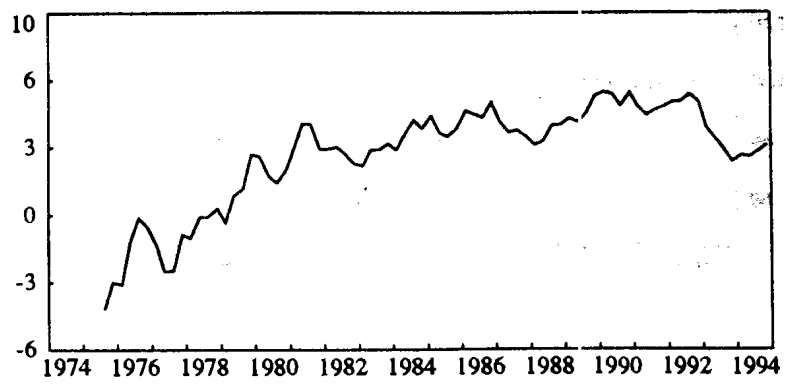

United States
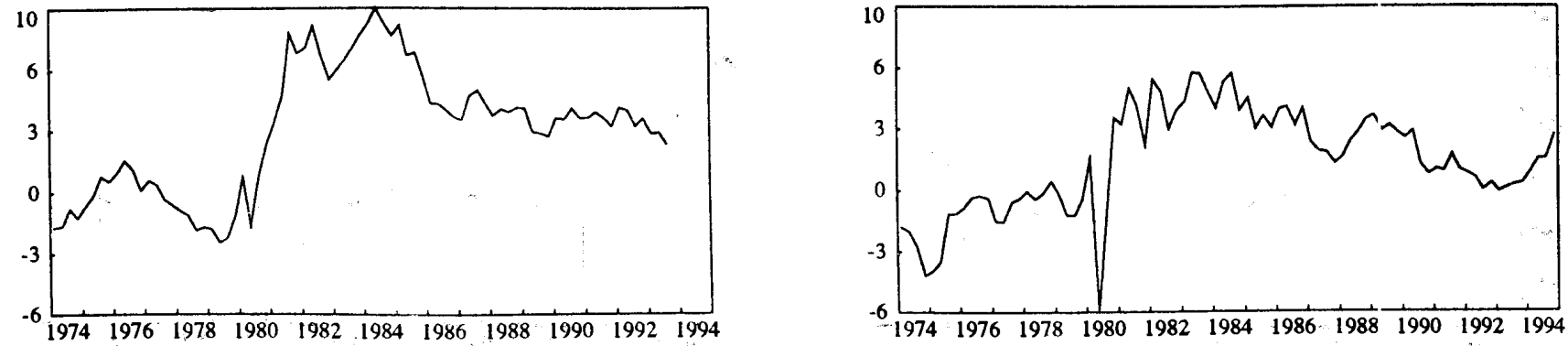
Figure 4

Standard: Real Interest Differentials and Real Exchange Rates (__ _

Long-Term

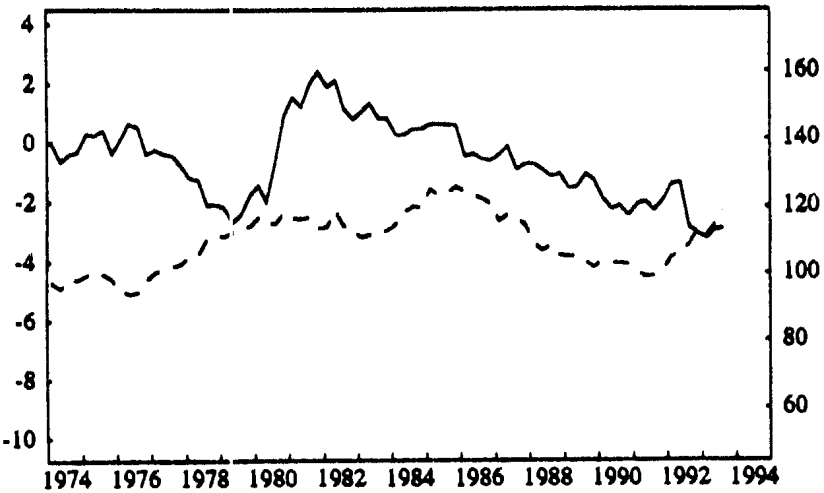

Short-Term

\section{Canada}

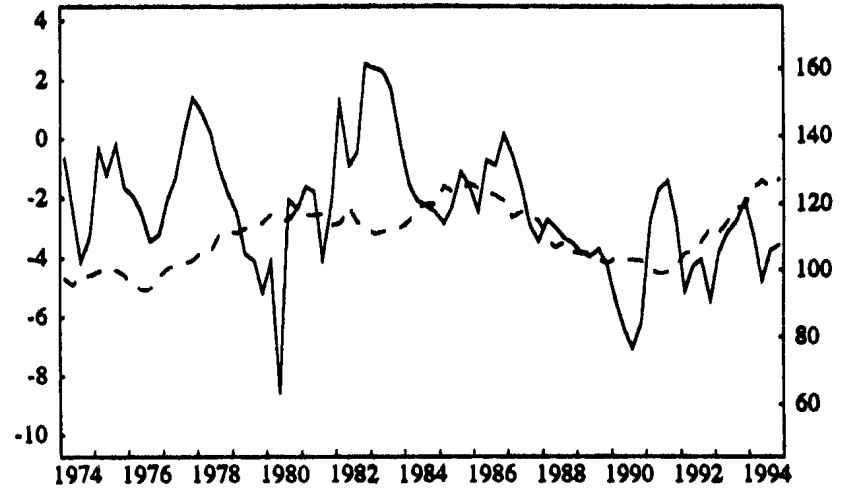

Germany
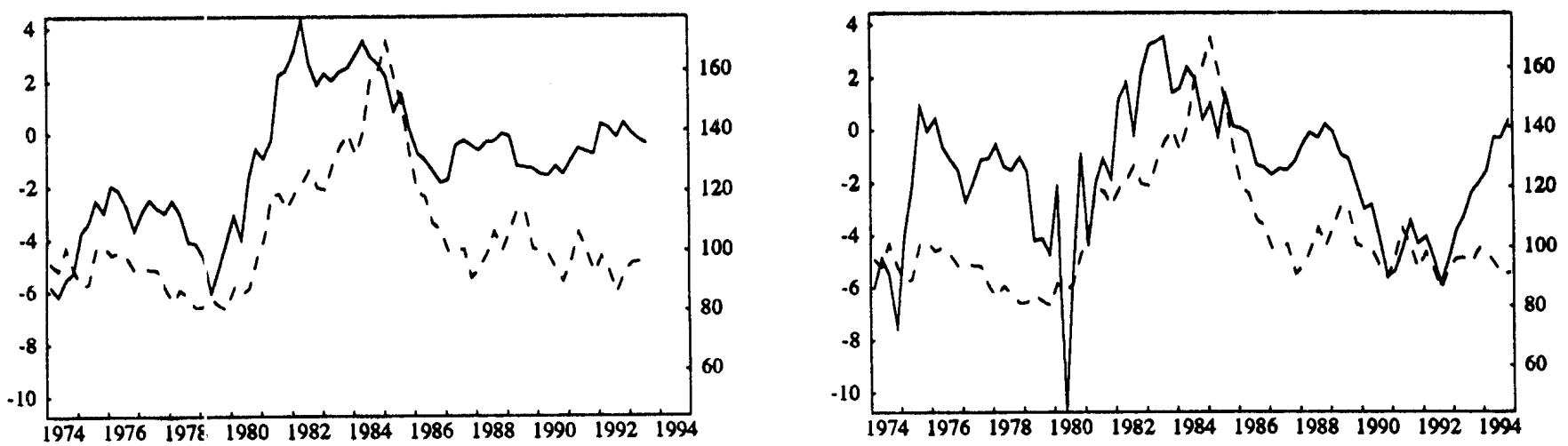

Japan
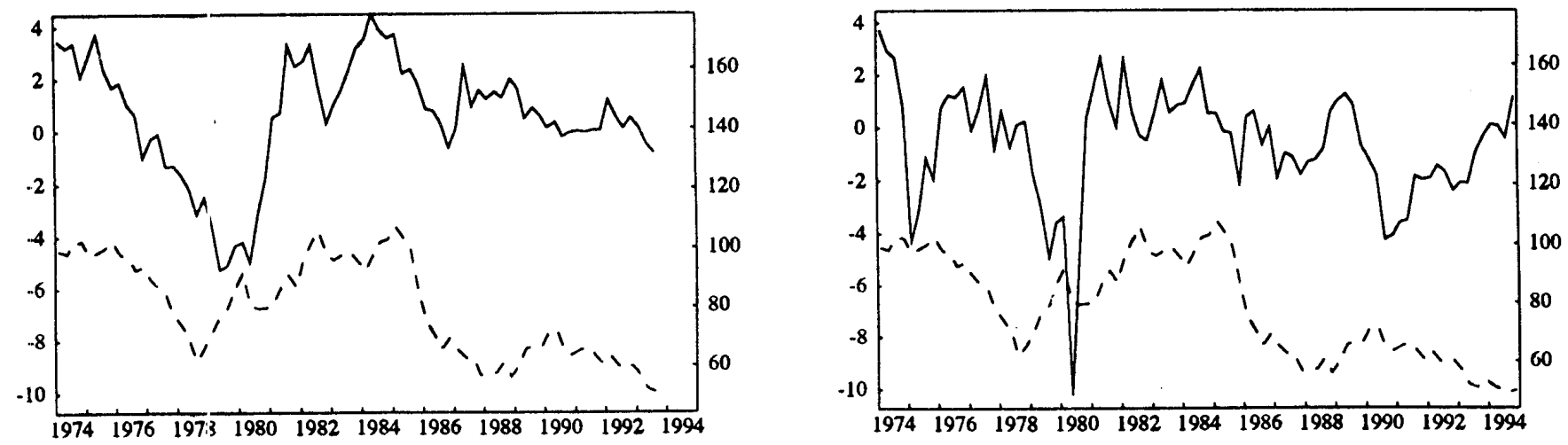

Trade-Weighted
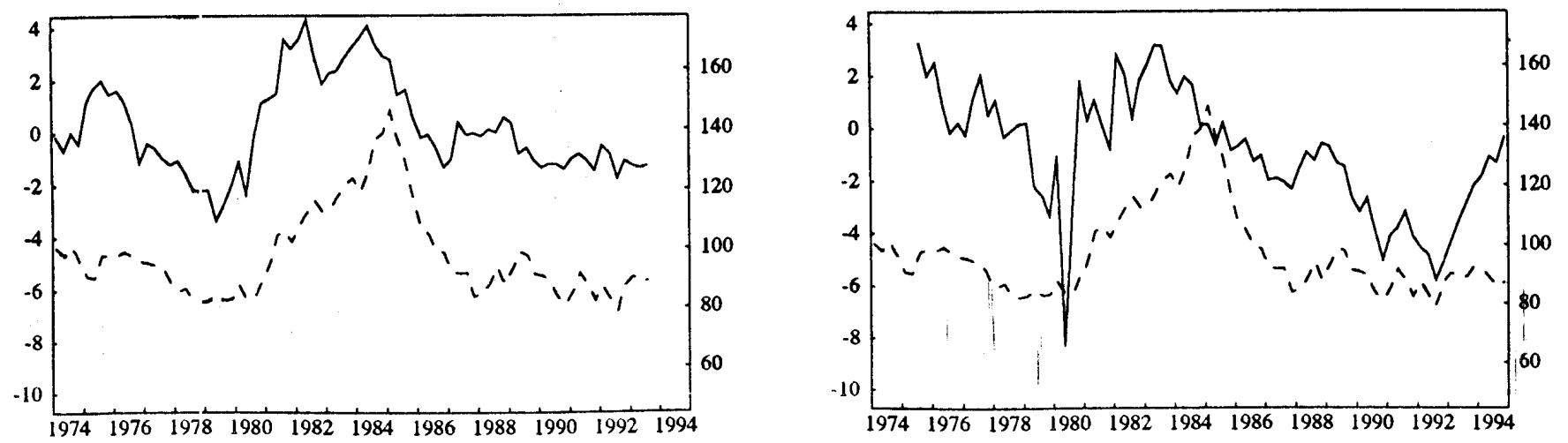
Figure 5

Ex Post: Real Interest Differentials

\section{Long-Term}

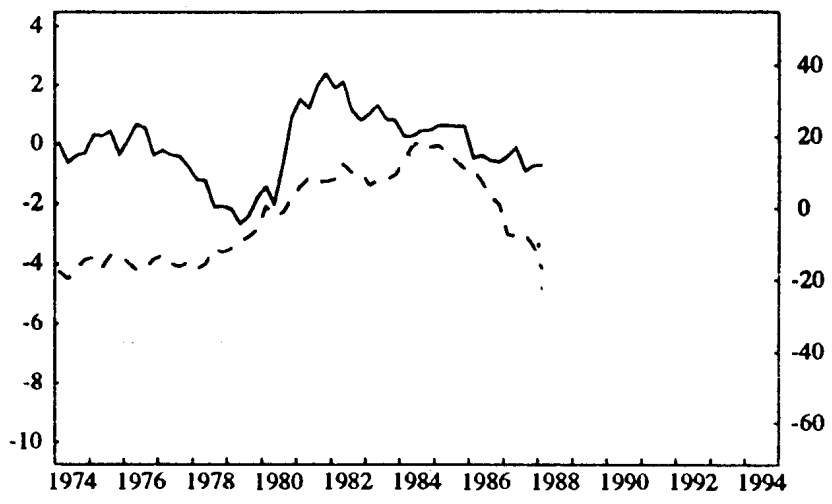

\section{) and Real Dollar Depreciation (__ _}

Canada

\section{Short-Term}

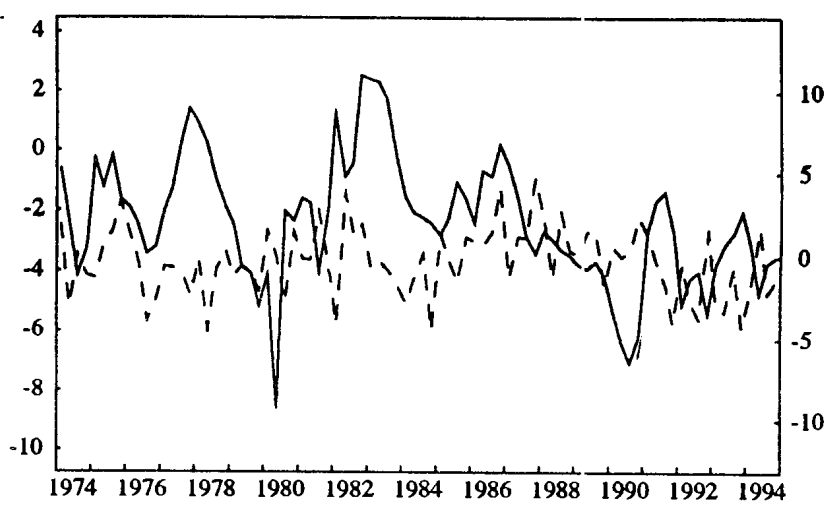

Germany
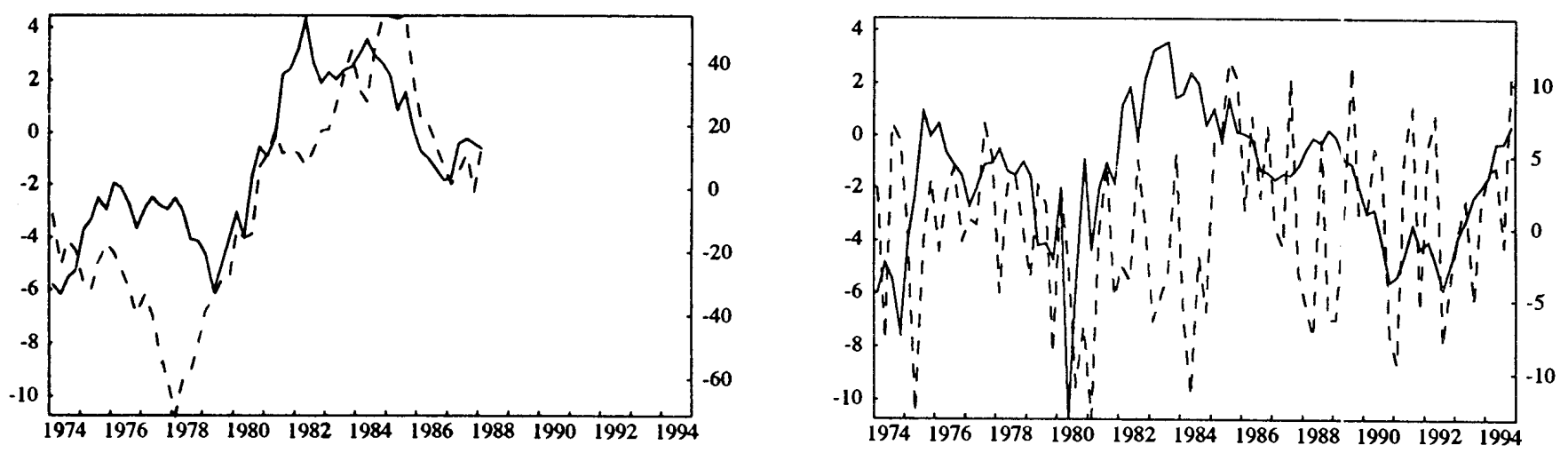

Japan
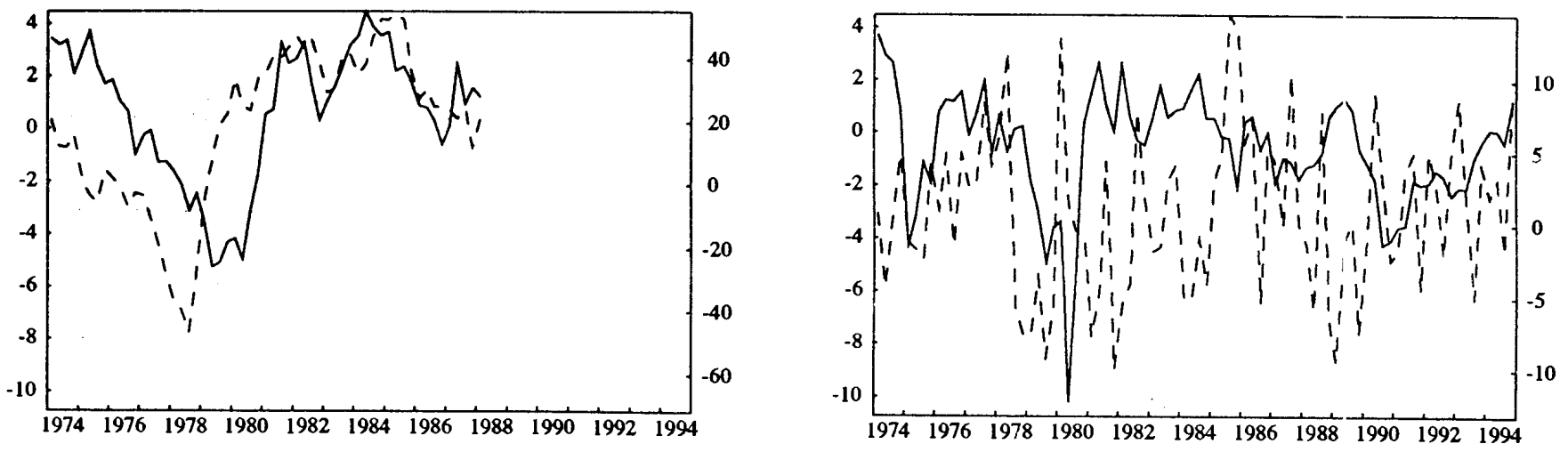

Trade-Weighted
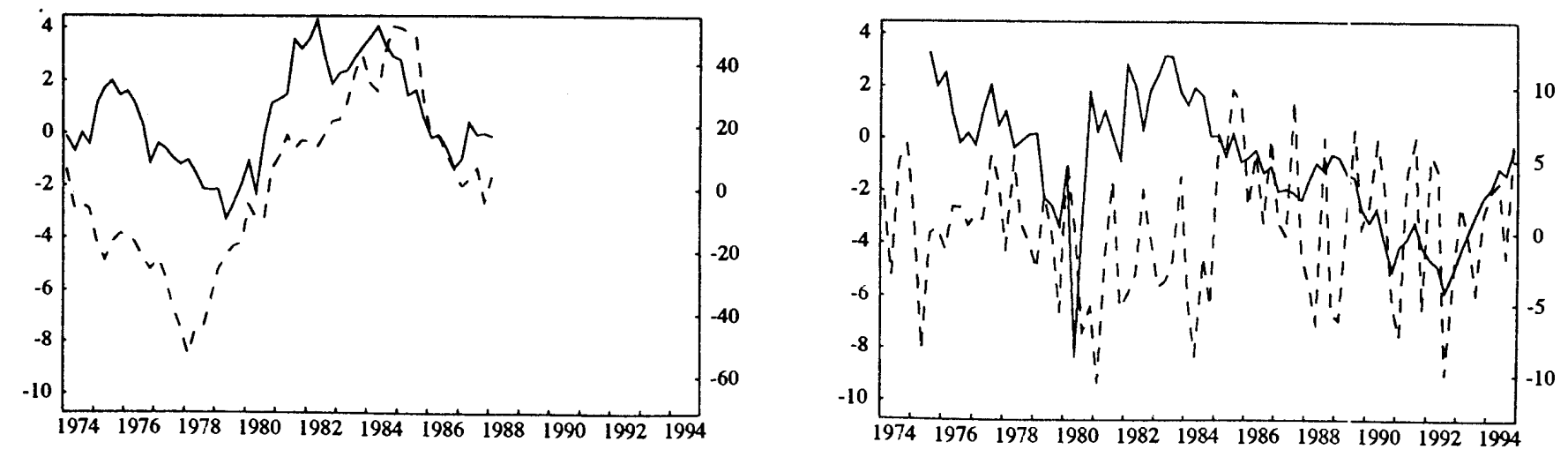


\section{International Finance Discussion Papers}

IFDP

Number
Titles

1995
518 Alternative Approaches to Real Exchange Rates and Real Interest Rates: Three Up and Three Down

517 Product market competion and the impact of price undertainty on investment: some evidence from U.S. manufacturing industries

$516 \quad$ Block Distributed Methods for Solving Multi-country Econometric Models

515 Supply-side sources of inflation: evidence frp, OECD countries

514 Capital Flight from the Countries in Transition: Some Theory and Empirical Evidence

513 Bank Lending and Economic Activity in Japan: Did "Financial Factors" Contribute to the Recent Downturn?

512 Evidence on Nominal Wage Rigidity From a Panel of U.S. Manufacturing Industries

511 Do Taxes Matter for Long-Run Growth?: Harberger's Superneutrality Conjecture

510 Options, Sunspots, and the Creation of Uncertainty

509 Hysteresis in a Simple Model of Currency Substitution

508 Import Prices and the Competing Goods Effect

507 Supply-side Economics in a Global Economy

506 The Lucas Critique In Practice: Theory Without Measurement

505
Real Exchange Rate Targeting and Macroeconomic Instability
Author(s)

Hali J. Edison

William R. Melick

Vivek Ghosal

Prakash Loungani

Jon Faust

Ralph Tryon

Prakash Loungani

Phillip Swagel

Nathan Sheets

Allan D. Brunner

Steven B. Kamin

Vivek Ghosal

Prakash Loungani

Enrique G. Mendoza

Gian Maria Milesi-Ferretti

Patrick Asea

David Bowman

Jon Faust

Martin Uribe

Phillip Swagel

Enrique G. Mendoza

Linda L. Tesar

Neil R. Ericsson

John S. Irons

Martin Uribe

Please address requests for copies to International Finance Discussion Papers, Division of

International Finance, Stop 24, Board of Governors of the Federal Reserve System,
Washington, D.C. 20551. 


\section{International Finance Discussion Papers}

IFDP

Number
Titles

1995

$504 \quad \ldots$ Inferences from Parametric and Non-Parametric Covariance Matrix Estimation Procedures

503 Exchange-Rate Based Inflation Stabilization: The Initial Real Effects of Credible Plans

$502 \quad$ Strategic Returns to International Diversification: An Application to the Equity Markets of Europe, Japan, and North America

501 Real Exchange Rate Movements in High Inflation Countries

500 Political Competition, Casual Relations Between Taxes and Spending, and Their Influence on Government Size: Evidence From State-Level Data

499 International Stock Price Spillovers and Market Liberalization: Evidence From Korea, Japan, and the United States

498 How Wide is the Border?

Constrained Suboptimality in Economies with Limited Communication

Saving-Investment Associations and Capital Mobility On the Evidence from Japanese Regional Data

Convertibility Risk, Default Risk, and the Mexdollar Anomaly

Government Budget Deficits and Trade Deficits Are Present-Value Constraints Satisfied in Long-Term Data?

$$
\text { Real Shocks and Real Exchange Rates in Really Long-Term }
$$
Data

1994
Author(s)

Wouter J. Den Haan
Andrew T. Levin

Martin Uribe

John Ammer

Jianping Mei

John H. Rogers

Ping Wang

Diane Lim Rogers

John H. Rogers

Sang W. Kim

John H. Rogers

Charles Engle

John H. Rogers

David Bowman

Robert Dekle

John H. Rogers

Shaghil Ahmed

John H. Rogers

John H. Rogers
David Bowman Deborah Minehert Matthew Rabin 